\title{
Investigation of the relationship between "Sella Turcica Brid- ge" and "Ponticulus Posticus": A Lateral Cephalometric Study
}

\author{
Investigación sobre la Relación entre "Puente Silla Turca" \\ y "Ponticulus Posticus": Un Estudio Cefalométrico lateral
}

Melek Tassoker' ${ }^{1}$ Hatice Kok $^{2}$ \& Sevgi Ozcan ${ }^{1}$

TASSOKER, M.; KOK, H. \& OZCAN, S. Investigation of the relationship between "Sella Turcica Bridge" and "Ponticulus Posticus": A lateral cephalometric study. Int. J. Morphol., 35(1):337-344, 2017.

SUMMARY: The ponticulus posticus (PP) is a bridge of bone sometimes found on the atlas vertebra surrounding the vertebral artery and the first cervical nerve root. Sella turcica bridging (STB) is the fusion of anterior and posterior clinoid processes. The objective of this study was to find out the association between STB and PP. For the study, 752 digital lateral cephalograms were retrieved from the archived records of Necmettin Erbakan University, Faculty of Dentistry, Konya, Turkey. There was a significant relationship between the presence of STB and PP $(\mathrm{p}=0.000, \mathrm{p}<0.001)$. This study indicates that there is a significant correlation between the presence of STB and PP.

KEY WORDS: Sella turcica; Lateral cephalometrics; Sella turcica bridging; Ponticulus posticus.

\section{INTRODUCTION}

The atlas is the first cervical vertebra of the spine. This cervical vertebra has several morphologic features that differentiate it from other vertebrae. Ponticulus Posticus (PP) is a variation occuring on the atlas vertebra (Bayrakdar $e t$ al., 2014). The PP means "little posterior bridge" in latin (Geist et al.; 2014; Sharma et al., 2010; Chitroda et al., 2013; Saokar \& Nawale, 2014; Cho, 2009; Mudit et al., 2014). PP manifests as a partial or complete bony arch/bridge in the atlas vertebra (Pérez et al., 2014). In the literature, there are many terms that describe this anomaly (Table I), however, its most accepted name is PP (Baba et al., 2015).

Complete ossification of atlanto-occipital membrane leads to arcuate foramen, which may cause external pressure on the vertebral artery, especially during extreme rotatory movements of the head (Unur et al., 2004). The potential clinical significance of PP is controversial because the majority of patients with this finding are asymptomatic (Mudit et al., Chitroda et al.) but this bony arch may be linked to different symptoms, ranging from neckache to headache and migraine and it may also be incorrectly assessed during orthopedic surgery for fixation of atlas-axis, with consequent risk of damaging the vertebral artery (Chitroda et al.). It is important for the anatomist, radiologist, neurophysicians and neurosurgeons who are dealing with this region. Most prevalence studies had been performed by plain radiographs or dried atlas specimens (Cho). Because of the anomaly can be seen complete or incomplete there is a disagreement about the frequency of complete and incomplete cases (Geist et al.). The prevalence of this anomaly in the literature varies widely, with reports ranging from $4.3 \%$ (Sharma et al.) - $68 \%$ (Baba et al.).

The centre of sella turcica is routinely used as a cephalometric landmark to act as a reference point, $\mathrm{S}$, for evaluating spatial position of both jaws as they relate to the cranial base. Anatomically sella turcica is a saddle-shaped depression in sphenoid bone which contains the pituitary gland (Shah et al., 2014). It consists four clinoid processes (two anterior and two posterior), the anterior border represented by tuberculum sellae and the posterior border by the dorsum sellae (Kucia et al., 2014). On a lateral cephalometric radiograph the image of sella turcica is $\mathrm{U}$ shaped (Shah et al.), it may be concave, flat or even convex (Kucia et al.). A deviation from normal size and shape of sella turcica can be an indication of a pathological condition of the gland (Shah et al.). Investigations concerning the se1la turcica have not only focused on size but also on morphology. A normal morphological variation of sella turcica must be considered as it may vary greatly from indi-

${ }^{1}$ Department of Oral and Maxillofacial Radiology, Faculty of Dentistry, Necmettin Erbakan University, Konya, Turkey.

${ }^{2}$ Department of Orthodontics, Faculty of Dentistry, Necmettin Erbakan University, Konya, Turkey. 
vidual to individual (Shah et al.; Nagaraj et al., 2015). The most frequent abnormality described in the orthodontic literature is sella turcica bridge (STB) (Kucia et al.). The fusion of anterior and posterior clinoid processes or a calcification of interclinoid ligament termed as STB (Shah et al., Kucia et al.). This osseous structure has been termed differently in the literature (Table II). The prevalence of STB or calcification of the interclinoid ligaments was reported in the literature between $1.1 \%$ (Alkofide, 2007) - $18.6 \%$ (Becktor et al., 2000).

Recently some studies have been done to establish connection of craniofacial skeletal anomalies with dental anomalies. It appears that tooth formation and tooth eruption and sella turcica bridging, as well as neck and shoulder skeletal development, are influenced by neural crest cells (Saokar \& Nawale). Our purpose in this study is to find out association between STB and PP.

Table I. Various names used to describe the ponticulus posticus (PP).

\begin{tabular}{l}
\hline NOMENCLATURE VARIATION FOR PP \\
\hline Arcuate foramen \\
Atlas bridging \\
Canalis arteriae vertebralis \\
Foramen arcuale \\
Foramen atlantoideum \\
Foramen retroarticular \\
Foramen sagittale \\
Kimmerle anomaly \\
Kimmerle deformity \\
Kimmerle variant \\
Pons posticus \\
Posterior atlantoid foramen \\
Posterior glenoid process \\
Posterior glenoid spiculum \\
Posterior ponticulus \\
Retroarticular ring \\
Retrocondylar bony foramen \\
\hline
\end{tabular}

Table II. Various names used to describe the sella turcica bridge.

\begin{tabular}{l}
\hline Nomenclature Varıation for STB \\
\hline inter clinoid taenia \\
inter clinoid bars \\
inter clinoid osseous bridge \\
sella turcica bridge/bridging \\
sella bridge \\
roofing / bulging / calcification of the diaphragma sellae \\
calcified / ossified interclinoid ligament \\
\hline
\end{tabular}

\section{MATERIAL AND METHOD}

After local institutional research ethics committee approval (no.\#2016.003), radiographs were retrieved from the archived records of Necmettin Erbakan University Faculty of Dentistry, Konya, Turkey. Orthodontic records, digital panoramic radiographs and digital lateral cephalograms from 752 patients, comprising 376 males and 376 females, within two age subgroups (9-15 and 16-24) were examined. The average age was 14.9-year-old (range 9-24 years). The distribution of the sample by age was presented in Table III.

Table III. Age distribution of the patient sample.

\begin{tabular}{ccc}
\hline Age class (y) & N & Percent (\%) \\
\hline $9-15$ & 452 & 60.1 \\
$16-24$ & 300 & 39.9 \\
Total & 752 & 100.0 \\
\hline
\end{tabular}

Digital lateral cephalometric radiographs were obtained in standart position by using J MORITA (2D Veraviewpocs, MFG corp, Kyoto, Japan) machine with a tube voltage of $65 \mathrm{kV}$, tube current of $10 \mathrm{~mA}$ and exposure time of $4.9 \mathrm{~s}$. The images were analyzed in a Dell Precision T7600 workstation (Dell, Round Rock, TX) using a 32-in Dell LCD screen with a resolution of 1280x1024 pixels in JPEG (Joint Photographic Experts Group) format.

\section{Inclusion criteria}

1. Healthy patients without any history of systemic diseases and long term use of drugs.

2. Patients in the age group of 9-24 years.

3. Patients advised for lateral cephalometric radiographs for orthodontic treatment.

4. High-quality radiographs which were taken by trained radiographic technicians in a standardized manner.

\section{Exclusion criteria}

1. Individuals with congenital defects in the craniofacial region like clefts and malformations

2. History of cranifacial fractures

3. Patients suffering from disorders of bone, nutritional deficiencies and endocrinal disturbances.

Each radiograph was carefully inspected for the presence of a STB and a PP, whether it was complete or partial (Fig. 1). Because we inspected neutral lateral radiograph only, we were not able to determine if the anomaly was uni or bilateral (Pérez et al., 2014). Direct visual method of examination under adequate illumination was used. 

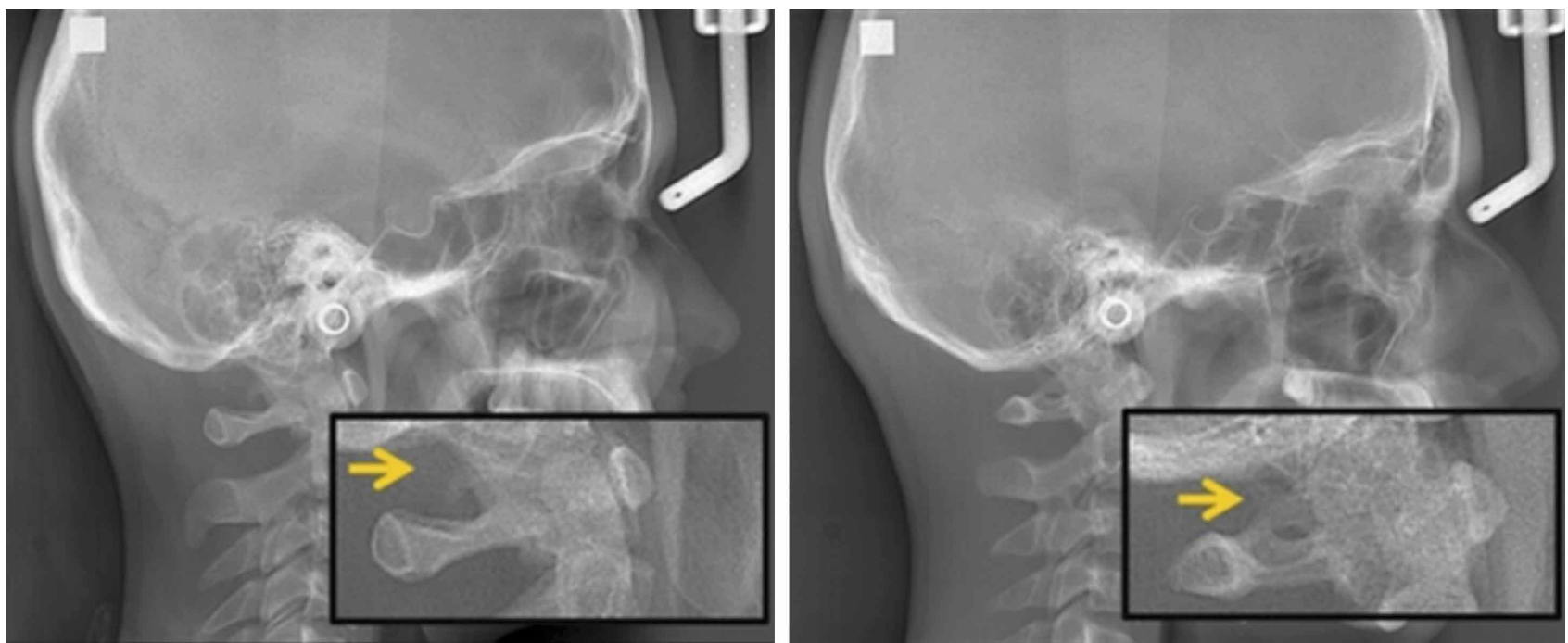

Fig. 1. Incomplete and complete form of PP.

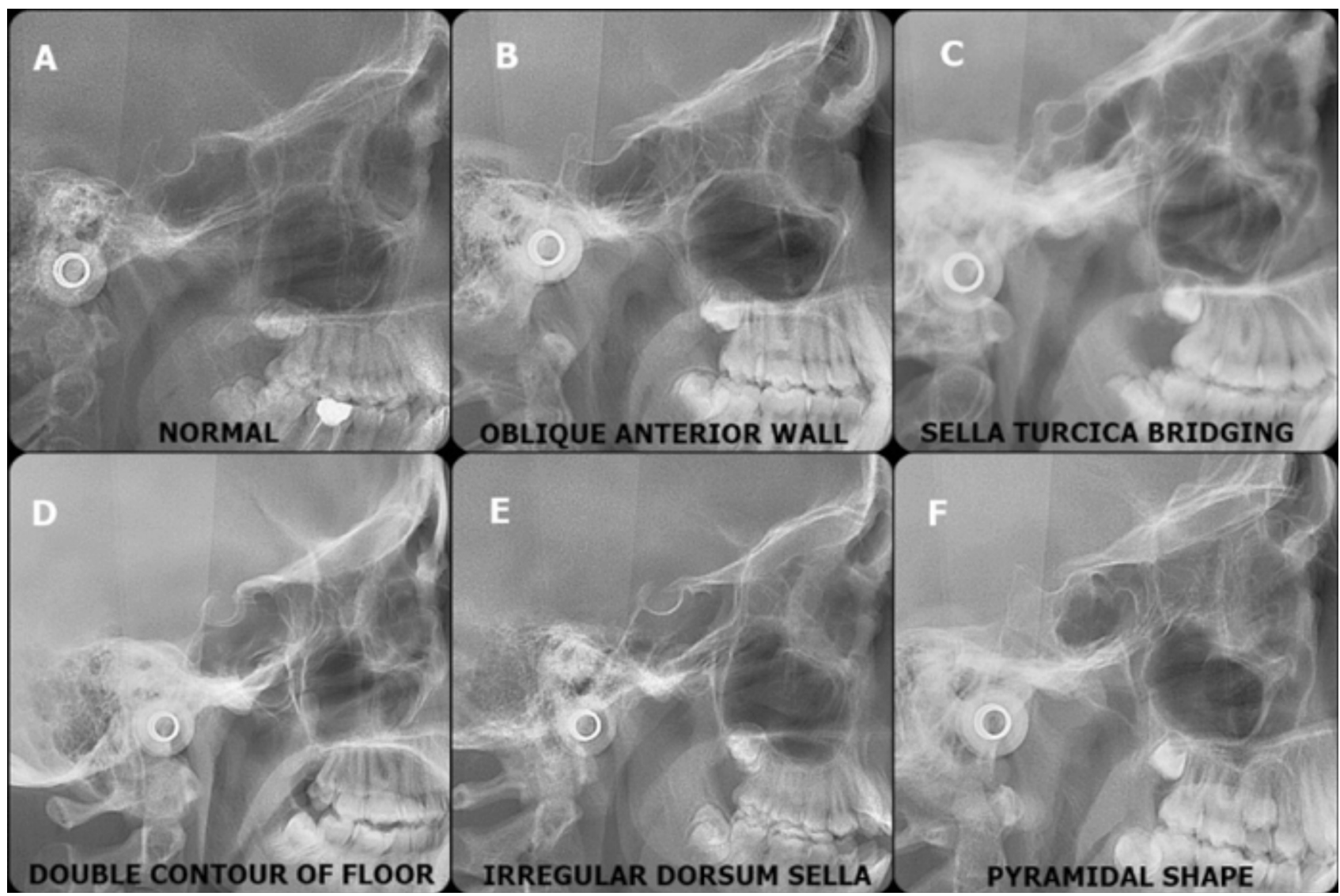

Fig. 2. Different morphological types of sella turcica according to Axelson et al: (a) normal sella turcica, (b) oblique anterior wall, (c) sella turcica bridge, (d) double contour of floor, (e) irregular dorsum sellae, (f) pyramidal shape. 


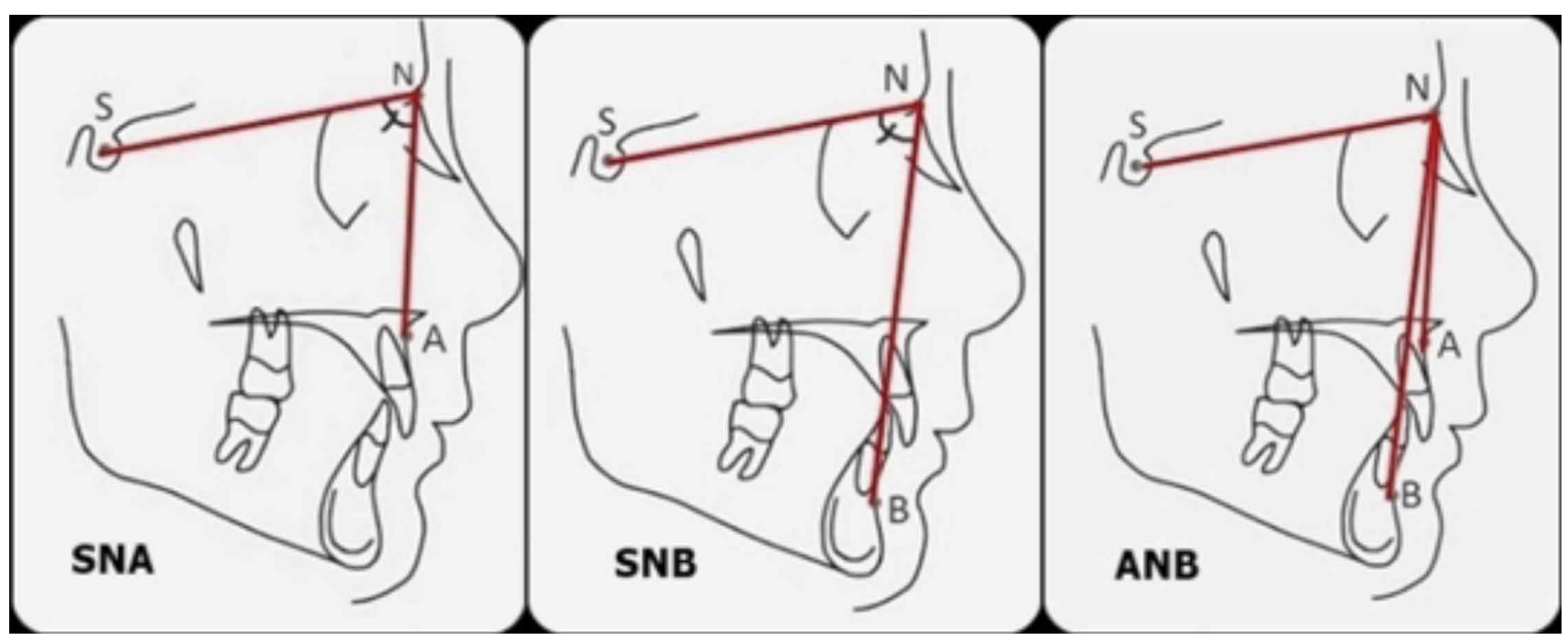

Fig. 3. Scheme used to determine the skeletal classes as for cephalometric measurements: Steiner's ANB angle on standart lateral cephalometric radiograph. $\mathrm{OP}=$ occlusal plane, $\mathrm{N}=$ nasion, $\mathrm{A}=$ subspinale and $\mathrm{B}=$ supramentale.

During initial examination all lateral cephalograms were observed by a radiologist and an orthodontist (MT and HK). To eliminate any error 100 randomly selected lateral cephalograms were re-examined separately by the same two authors 1 month after initial examination. There was almost perfect agreement between the two authors and the two examinations.

Shape and morphological appearance of sella turcica were assessed according to the method described by Axelsson et al. (2004) (Fig. 2). Orthodontic classification was carried out using Steiner analysis. Based upon the ANB angle, subjects were classified into Class I, II and III. ANB angle of \pm 2 belongs to Class I skeletal base. ANB angle $>4$ belongs to Class II skeletal base and ANB angle $<0$ belongs to Class III skeletal base (Fig. 3).

A chi-square test was used to find out the association of STB and PP. All statistical analyses were performed using SPSS 21.0 (Statistical package for social science Inc. Chicago, USA).

Table IV. Distribution of sella turcica type.

\begin{tabular}{lcc}
\hline \multicolumn{1}{c}{ Sella type } & Frequency & Percentage (\%) \\
\hline Normal sella turcica & 231 & 30.7 \\
Oblique anterior wall & 62 & 8.2 \\
Sella turcica bridge & 182 & 24.2 \\
Double contour of floor & 22 & 2.9 \\
Irregular dorsum sellae & 122 & 16.2 \\
Pyramidal shape & 133 & 17.7 \\
Total & 752 & 100.0 \\
\hline
\end{tabular}

Table V. Subjects grouped according to skeletal class.

\begin{tabular}{ccc}
\hline Skeletal class & Frequency & Percentage (\%) \\
\hline I & 231 & 30.7 \\
II & 411 & 54.7 \\
III & 110 & 14.6 \\
Total & 752 & 100.0 \\
\hline
\end{tabular}

Table VI. PP distribution among patients.

\begin{tabular}{lcc}
\hline PP & N & Percentage (\%) \\
\hline Normal & 562 & 74.7 \\
Incomplete & 111 & 14.8 \\
Complete & 79 & 10.5 \\
Total & 752 & 100.0 \\
\hline
\end{tabular}

\section{RESULTS AND DISCUSSION}

The morphology of sella turcica appeared to be normal in shape $30.7 \%$ of subjects, regardless of sex, age, or skeletal type (Table IV). Table V shows the distribution of skeletal classes of patients. The majority of subjects were in class II. There was no statistically significant difference between skeletal classes and sella turcica bridging $(\mathrm{p}>0.05)$.

The prevalence of incomplete and complete calcification of PP were given in Table VI. No statistically significant association were observed between skeletal classes and PP $(\mathrm{p}>0.05)$. 
Table VII. Association between sex and PP. sex and sella bridging (*significant).

\begin{tabular}{lcc}
\hline \multirow{2}{*}{ Age (y) } & \multicolumn{2}{c}{ Prevalence } \\
\cline { 2 - 3 } & Sella Bridging & PP \\
\hline $9-15$ & $20 \%$ & $23 \%$ \\
$16-24$ & $30 \%$ & $28 \%$ \\
p value & $0.001 *$ & 0.307 \\
\hline
\end{tabular}

Table VIII. Associaton between sex and PP, sex and sella bridging.

\begin{tabular}{lcc}
\hline Sex & \multicolumn{2}{c}{ Prevalence } \\
\cline { 2 - 3 } & Sella Bridging & PP \\
\hline Female & $23 \%$ & $21 \%$ \\
Male & $24 \%$ & $28 \%$ \\
p value & 0.466 & 0.076 \\
\hline
\end{tabular}

STB and PP prevalence were increased by aging (Table VII). Although there was statistically significant association between age and sella bridging, there was no statistically difference between age and PP. No statistically significant association were observed between sex and PP, sex and sella bridging.

Although males had higher values of prevalence, no statistically significant association were observed between sex and PP, sex and sella bridging (Table VIII).

The prevalence of incomplete, complete PP and STB was $14.8 \%, 10.5 \%$ and $24.2 \%$, respectively. There was statistically significant association between STB and PP

Table IX. Association between STB and PP (*significant).

\begin{tabular}{|c|c|c|c|c|}
\hline \multirow[t]{2}{*}{ Patients } & \multicolumn{2}{|c|}{ PP } & \multirow[t]{2}{*}{ Total } & \multirow{2}{*}{$\begin{array}{c}\text { p- } \\
\text { value }\end{array}$} \\
\hline & $\begin{array}{c}\text { Present } \\
\text { (N) }\end{array}$ & $\begin{array}{c}\text { Absent } \\
\text { (N) }\end{array}$ & & \\
\hline $\begin{array}{l}\text { With sella } \\
\text { bridging }\end{array}$ & 78 & 104 & 182 & $0.000 *$ \\
\hline $\begin{array}{l}\text { Without sella } \\
\text { bridging }\end{array}$ & 112 & 458 & 570 & \\
\hline Total & 190 & 562 & 752 & \\
\hline
\end{tabular}

Table X. Association between PDC and sella bridging, PDC and PP (*significant)

\begin{tabular}{lcc}
\hline Patients & \multicolumn{2}{c}{ Prevalence } \\
& Sella bridging (\%) & PP (\%) \\
\hline With PDC & 26 & 29 \\
Without PDC & 25 & 25 \\
p value & 0.171 & $0.040^{*}$ \\
\hline
\end{tabular}

( $\mathrm{p}<0.001)$. PP was found to be present more in the subjects with sella bridging compared to subjects without bridging (Table IX).

The prevalence of PP was increased in patients with palatally displaced canines $(P D C)(p<0.05)$ but there was no statistically significant differences were observed between sella bridging and PDC ( $\mathrm{p}>0.05)$ (Table X).

\section{DISCUSSION}

The lateral cephalograph is the most common diagnostic radiograph used in clinical orthodontics (Mudit et al., Sharma et al.). They are used to evaluate the craniofacial and dental structures, but they also include other diagnostics information about the skull, face and upper cervical spine, and various occult pathologies and rare normal variants involving the head or spine (Pérez et al., 2013). Identifying the affected side of atlas is very difficult with lateral radiographic views because the presentation of PP can be uni or bilateral. The exact characterization is possible only by three dimensional (3D) computed tomography (CT) reconstruction (Pérez et al., 2014). Additionaly cone beam CT (CBCT) has great advantages over planar skull radiography in visualizing the cervical vertebrae. CBCT provides demonstration of the vertebral column in three planes of space, thereby providing the benefits of conventional CT with generally lower radiation exposure and greater spatial resolution (Geist et al.). Plain film radiographs are useful to indicate the presence of PP; but the detection of the osseous bridges on plain film radiographs depends on the thickness of the bridge, a fine thread of ossification may be difficult to detect and thinner bridges are detected using 3D CT scanning only (Pérez et al., 2014). Cho, compared 3D CT scans against plain film radiography and found statistically significant differences in the frequencies of the two types of radiographic studies influenced by the different diagnostic values of CT scans contrasted with the plain film radiography.

Autopsy studies have reported lower rates of STB compared with the higher rates found in radiographic studies. The differences between direct anatomical studies and data from lateral cephalometric radiographs have been attributed to superimposition of the overlapping clinoid processes of the sella turcica (Abdel-Kader, 2007). For this reason, only three dimensional imaging such as CT or CBCT could give more precise information about the sella area. However, routine use of these imaging techniques in patients is not advised due to the higher exposure to radiation, particularly with CT. 
Table XI. The prevalence of PP as reported in the literature.

\begin{tabular}{lcclc}
\hline Authors & Year & Sample size & Review source & Prevalence (\%) \\
\hline Unur et al. & 2004 & 351 & Lateral spine radiographs & 5.1 \\
Sharma et al. & 2009 & 228 & Lateral cephalographs & 4.3 \\
Chitroda et al. & 2013 & 500 & Lateral cephalographs & 60 \\
Bayrakdar et al. & 2014 & 730 & CBCT & 17.4 \\
Pérez et al. & 2014 & 1056 & Lateral cephalographs & 19.79 \\
Geist et al. & 2014 & 576 & CBCT & 26.2 \\
Baba et al. & 2015 & 1000 & Lateral cephalographs & 68 \\
Present study & 2016 & 752 & Lateral cephalographs & 25.3 \\
\hline
\end{tabular}

Table XII. The prevalence of sella bridging in the literature

\begin{tabular}{lclc}
\hline Author & Year & Sample Size-Source & Prevalence (\%) \\
\hline Becktor et al. & 2000 & 177-Lateral cephalometrics & 18.6 \\
Erturk et al. & 2004 & 119-Dry skull & 8.18 \\
Alkofide. & 2007 & 180-Lateral cephalometrics & 1.1 \\
Kolagi et al. & 2011 & 112-Dry skull & 8.04 \\
Pérez et al. & 2013 & 417-Lateral cephalometrics & 4.31 \\
Nagaraj et al. & 2015 & 200-Lateral cephalometrics & 7.5 \\
Present study & 2016 & 752-Lateral cephalometrics & 24.2 \\
\hline
\end{tabular}

In this investigation, the overall prevalence of complete and incomplete PP was $25.3 \%$, similar to the results of some researchers (Geist et al.; Pérez et al.; 2014). Other authors, however, have reported a smaller percentage of PP (Unur et al.; Sharma et al.). The prevalence of PP has been reported to be between $4.3 \%$ (Sharma et al.) and $68 \%$ (Baba et al.). Researchs in the literature represent many different ethnic and racial groups, which may explain the wide range of prevalence (Geist et al.). Mudit et al., suggested that ethnicity could change the prevalence of this entity. Standardization and disagreement between observers are anohter problems, making comparisons between reports difficult (Geist et al.). There are also many factors determining the visibility of PP in radiographic images such as film processing and proper selection of $\mathrm{kVp}$ and $\mathrm{mAs}$.

We found increasing percentages of PP from the youngest to the oldest age group in accordance with Geist $e t$ $a l$. This suggests that PP bridges may form more frequently after puberty (Geist et al.). Various theories have been put forward by different researchers for the origin of the bridges leading to the foramen formation. The mechanism of formation is not clearly understood and a subject of much debate but a number of theories have been put forward including (Tubbs et al., 2007): a genetic trait, a remnant manifestation of an occipital vertebra, the result of external mechanical factors such as carrying heavy objects on the head, an ossification related with increasing age, and the activation of a special osteogenic potency existent in the craniocervical junction region in the connective tissue surrounding the vertebral artery possibly induced by the pulsation of the vertebral artery.
This study found a higher percentage of males with PP but there is no consensus regarding the prevalence of PP in males compared with females (Geist et al.). The frequency of PP increased in subjects with palatally displaced canines in accordance with Leonardi et al. (2009). It may act as a useful diagnostic predictor of susceptibility to local dental problems.

The prevalence of STB shows great variation among different populations between $1.1 \%$ (Alkofide)-18.6\% (Becktor et al.). According to our results STB (24.2\%) are not so infrequent radiographic findings in Turkish orthodontic patients. The prevalence of STB was higher in the older age group in the present study but it also could be seen in the younger age group. Formation of the STB may result directly from the pattern of sphenoid development or can be dictated by the physiological activities of chemical compounds that are involved in embryogenesis and build up of the bones (Skrzat et al., 2006).

There was a clear tendency towards a greater frequency of a STB in patients with severe craniofacial deviations (Becktor et al.). The morphological variations of sella turcica with greater severity are more commonly seen in syndromic patients such as Down's syndrome, William's syndrome and Seckel syndrome (Nagaraj et al.). The occurence of STB has been described as a radiographic feature in basal cell carcinoma (Gorlin-Goltz) syndrome, Rieger syndrome, Axenfeld-Rieger syndrome and other disorders and syndromes. Sellar bridges were demonstrated radiographically to a $25 \%$ extent in idiots, to $20 \%$ in 
criminals, to $15 \%$ in epileptics, and to $38 \%$ in other cases with mental disorders (Kolagi et al., 2011).

The interclinoid ligament bisects the wall of the cavernous sinus, dividing it into two triangles; carotid trigone anteromedially and occulomotor trigone posterolaterally. Thus ossification of this ligament may influence such structures as the internal carotid artery or the occulomotor nerve. Anomalies of sellar region may create difficulty in the regional surgery planning. Removing the anterior clinoid process is an important step in exposing the structures in the cavernous sinus and is highly complicated due to the neuronal and vascular realtionships. The presence of ossified interclinoid ligament makes the removal of anterior clinoid process more difficult and increases the risks especially in the presence of aneurysm (Kolagi et al.).

Our results indicated that there was a statistically significant association between STB and PP. This relationship may be based on the involvement of neural crest cells and/or homeobox or hox genes during the developmental stage (Saokar \& Nawale). Our results in contrast with Leonardi et al. They did not found any relationship between STB and PP, but we are in accordance with the study done by MacRae (1953) and Saokar \& Nawale. Mac Rae found out the different variants of atlas could be accompanied by other defects within the vertebral column, such as deformation of the skull base, particularly within the Turkish saddle, extended styloid process or cervical ribs. Saokar \& Nawale observed that the incidence of PP was to be more in the group with sella bridging as compared to the group without bridging.

It appears that tooth formation and their eruption and sella turcica bridge calcification, as well as neck and shoulder skeletal development, are all influenced by neural crest cells. Because the teeth, the head, and the cervical spine are influenced in their development by neural crest cells, it is reasonable to assume that any disturbance of neural crest cells might interfere with the development of one or more systems that are under their influence (Leonardi et al.)

Sekerci et al. (2015) suggested that there was a significant relationship between the presence of PP and elongated styloid process. According to our study there was a significant association between STB and PP. Based on these results future researchs into the molecular basis of craniofacial and skeletal abnormalities could benefit from the reporting of new clinical interrelationships such as those presented here (Leonardi et al.).

In conclusion this study suggests that there is a significant correlation between the presence of PP and STB.
Bearing this in mind, our findings should widen the idea somewhat that PP is seen only in conjunction with STB or other skull and skeletal anomalies. If PP and STB are associated with other clinically and radiologically discernible features that often occur together and could be regard as part of a syndrome.

TASSOKER, M.; KOK, H. \& OZCAN, S. Investigación sobre la relación entre "puente silla turca" y "Ponticulus Posticus": Un estudio cefalométrico lateral. Int. J. Morphol., 35(1):337-344, 2017.

RESUMEN: El Ponticulus Posticus (PP) es un puente de hueso que se encuentra, a veces, en el atlas y rodea la arteria vertebral y la primera raíz del nervio cervical. El puente de la silla turca (PST) es la fusión de los procesos clinoides anteriores y posteriores. El objetivo de este estudio fue conocer la asociación entre PST y PP. Para el estudio, fueron utilizados 752 cefalogramas digitales laterales, obtenidos de los registros archivados de la Facultad de Odontología de la Universidad Necmettin Erbakan, Konya, Turquía. Hubo una relación significativa entre la presencia de PST y $\mathrm{PP}(\mathrm{p}=0,000, \mathrm{p}<0,001)$. Este estudio indica que existe una correlación significativa entre la presencia de PST y PP.

PALABRAS CLAVE: Silla turca; Cefalometría lateral; Puente silla turca; Ponticulus Posticus.

\section{REFERENCES}

Alkofide, E. A. The shape and size of the sella turcica in skeletal Class I, Class II, and Class III Saudi subjects. Eur. J. Orthod., 29(5):457-63, 2007.

Axelsson, S.; Storhaug, K. \& Kjaer, I. Post-natal size and morphology of the sella turcica. Longitudinal cephalometric standards for Norwegians between 6 and 21 years of age. Eur. J. Orthod., 26(6):597-604, 2004.

Baba, I. A.; Shah, A. F.; Yousuf, A.; Adhnan, M. F.; Manzoor, H. \& Safdar, Z. Prevalence of Ponticulus Posticus in Kashmiri population. Ann. Dent. Spec., 3(1):6-8, 2015.

Bayrakdar, I. S.; Miloglu, O.; Altun, O.; Gumussoy, I.; Durna, D. \& Yilmaz, A. B. Cone beam computed tomography imaging of Ponticulus Posticus: prevalence, characteristics, and a review of the literature. Oral Surg. Oral Med. Oral Pathol. Oral Radiol., 118(6):e210-9, 2014.

Becktor, J. P.; Einersen, S. \& Kjaer, I. A sella turcica bridge in subjects with severe craniofacial deviations. Eur. J. Orthod., 22(1):69-74, 2000.

Chitroda, P. K.; Katti, G.; Baba, I. A.; Najmudin, M.; Ghali, S. R.; Kalmath, B. \& Vijay, G. Ponticulus Posticus on the posterior arch of atlas, prevalence analysis in symptomatic and asymptomatic patients of Gulbarga population. J. Clin. Diagn. Res., 7(12):3044-7, 2013.

Cho, Y. J. Radiological analysis of Ponticulus Posticus in Koreans. Yonsei Med. J., 50(1):45-9, 2009.

Erturk, M.; Kayalioglu, G. \& Govsa, F. Anatomy of the clinoidal region with special emphasis on the caroticoclinoid foramen and interclinoid osseous bridge in a recent Turkish population. Neurosurg. Rev., 27(1):226, 2004.

Geist, J. R.; Geist, S. M. \& Lin, L. M. A cone beam CT investigation of Ponticulus Posticus and lateralis in children and adolescents. Dentomaxillofac. Radiol., 43(5):20130451, 2014.

Kolagi, S.; Herur, A.; Patil, G. \& Rairam, G. B. Complete sella turcica 
bridges prevalence and dimensions. J. Anat. Soc. India, 60(1):22-5, 2011.

Kucia, A.; Jankowski, T.; Siewniak, M.; Janiszewska-Olszowska, J.; Grocholewicz, K.; Szych, Z. \& Wilk, G. Sella turcica anomalies on lateral cephalometric radiographs of Polish children. Dentomaxillofac. Radiol., 43(8):2014065, 2014.

Leonardi, R.; Barbato, E.; Vichi, M. \& Caltabiano, M. Skeletal anomalies and normal variants in patients with palatally displaced canines. Angle Orthod., 79(4):727-32, 2009.

MacRae, D. L. Bony abnormalities in the region of the foramen magnum: correlation of the anatomic and neurologic findings. Acta Radiol., 40(23):335-54, 1953.

Mudit, G.; Srinivas, K. \& Satheesha B. H., R. Retrospective analysis of Ponticulus Posticus in indian orthodontic patients-a lateral cephalometric study. Ethiop. J. Health Sci., 24(4):285-90, 2014.

Nagaraj, T.; Shruthi, R.; James, L.; Keerthi, I.; Balraj, L. \& Goswami, R. D. The size and morphology of sella turcica: A lateral cephalometric study. J. Med. Radiol. Pathol. Surg., 1(3):3-7, 2015.

Pérez, I. E.; Chávez, A. K. \& Ponce, D. Frequency of sella turcica bridge and clinoid enlargement in lateral cephalometric plain film radiography from Peruvians. Int. J. Morphol., 31(2):373-7, 2013.

Pérez, I. E.; Chávez, A. K. \& Ponce, D. Frequency of Ponticulus Posticus in lateral cephalometric radiography of Peruvian patients. Int. J. Morphol., 32(1):54-60, 2014.

Saokar, P. C. \& Nawale, S. Radiographic correlative study of Ponticulus Posticus in dental patients. Indian J. Appl. Res., 4(5):503-5, 2014.

Sekerci, A. E.; Soylu, E.; Arikan, M. P. \& Aglarci, O. S. Is there a relationship between the presence of Ponticulus Posticus and elongated styloid process? Clin. Imaging, 39(2):220-4, 2015.

Shah, A. M.; Bashir, U. \& Ilyas, T. The shape and size of the sella turcica in skeletal class I, II \& III in patients presenting at Islamic International Dental Hospital, Islamabad. Pak. Oral Dent. J., 31(1):104-10, 2011.

Sharma, V.; Chaudhary, D. \& Mitra, R. Prevalence of Ponticulus Posticus in Indian orthodontic patients. Dentomaxillofac. Radiol., 39(5):277-83, 2010.

Skrzat, J.; Szewczyk, R. \& Walocha, J. The ossified interclinoid ligament. Folia Morphol. (Warsz.), 65(3):242-5, 2006.

Tubbs, R. S.; Johnson, P. C.; Shoja, M. M.; Loukas, M. \& Oakes, W. J. Foramen arcuale: anatomical study and review of the literature. $J$. Neurosurg. Spine, 6(1):31-4, 2007.

Unur, E.; Erdog an, N.; Ülger, H.; Ekinci, N. \& Ömer, Ö. Radiographic incidence of complete arcuate foramen in Turkish population. Erciyes Med. J., 26(2):50-4, 2004.

\author{
Corresponding Author: \\ Melek Tassoker \\ Necmettin Erbakan University \\ Faculty of Dentistry \\ Department of Oral and Maxillofacial Radiology, 42050 \\ Konya \\ TURKEY
}

E-mail: dishekmelek@gmail.com

Received: 01-07-2016

Accepted: 26-12-2016 